\title{
Impact of Ecological Friendly Treatments on Meloidogyne incognita Infected Ground Cherry
}

\section{S. Abo-Korah}

Econ. Entomol. and Agric. Zool. Dept., Fac. Agric., Menoufia Univ., Shibin El-Kom, Egypt.

Corresponding author email: abokora_2030@yahoo.com

\begin{abstract}
The main efforts of scientists to reduce appliance of nematicides that are commonly found in the markets, led to an increase in the demand safety, effective and environment friendly alternatives. Hence, the present research aims to test three safety and effective substances (Potassium silicate; Furfural and Albendazole) single or in combination in the control of root-knot nematode, Meloidogyne incognita infecting ground cherry plants (Physalis pruinosa L.) under field conditions. The obtained results revealed that all tested materials decreased $M$. incognita $\mathrm{J}_{2}$ population density. Individual treatments gave average reduction percentages of $M$. incognita $\mathrm{J}_{2}$ as: Potassium silicate 39.4\%; Furfural 55.9\% and Albendazole 52.1\%. The triple treatment (Potassium silicate + Furfural + Albendazole) gave the best results, as it led to decrease in the number of $M$. incognita $\mathrm{J}_{2}$ by $72.3 \%$ more than that occurred by the chemical nematicide (Oxamyl 24\%), which gave a reduction percentage of $65.6 \%$. The triple treatment also led to decrease in the numbers of mature females; egg masses and root gall index by $96.5,95.4$ and $83.3 \%$, respectively, while the Oxamyl $24 \%$ gave $86.9,90.5$ and $83.3 \%$, respectively. In addition, the triple treatment caused improvement in the vegetative and fruiting characteristics of treated plants. Thus, triple treatments can be recommended as a safety alternative for plants and humans instead of chemical nematicides in integrated nematode control programs.
\end{abstract}

Keywords: Meloidogyne incognita, Potassium silicate, Furfural, Albendazole, Ground cherry.

\section{INTRODUCTION}

Ground cherry, Physalis pruinosa L. (Family: Solanaceae) has economic and therapeutic importance as its fruit protected by an accrescent calyx and covered by a brilliant yellow peel and contains many important vitamins for the body, as it is rich in many beneficial elements for diabetics, strengthening the immune system and reducing high blood pressure (Kumagai et al., 2021; Puente et al., 2011). The rootknot nematode, Meloidogyne spp. is one of the most widespread genus and its host range is wide, as it parasites on many vegetables, fruit and field crops in addition to some ornamental plants and leads to a complete loss of yield (Saad et al., 2010). Rootknot nematodes attack the roots of Physalis pruinosa plants, causing damage and great economic loss (Abo-Korah, 2017).

Silicon (Si) considered as the second element after oxygen in the percentage of its presence in the earth's crust and reduces the toxic effect on plants caused by increased salinity; dehydration and exposure to heavy metals (Ye et al., 2013). Silicon increases the ability of plants to withstand temperatures and droughts; prevent the 
penetration of fungi, bacteria and nematodes into the cortex of plants, as it is concentrated at the site of penetration of the pest and prevents it from income and thus reduce the incidence of diseases (Gad, 2019). It is considered to have a major role in increasing plant resistance to pests (Dannon and Wydra, 2004).

Furfural is an organic substance that is easily soluble and decomposed in water and the soil as well as is not polluting the environment. It has a negative effect on Meloidogyne incognita egg hatching, juveniles viability and root penetration rate. Accordingly, it must be taken into account that furfural is a suitable alternative to first-class nematicide (Fabiyi, 2020; Abdelnabby et al., 2016).

Albendazole is a medicine used for the treatment of a variety of zooparasitic nematode infestations and broad spectrum antinematodes. The principal mode of action is by its inhibitory effect on tubulin polymerization which results in the loss of cytoplasmic microtubules in the intestines of nematodes, ultimately causing energy depletion and death of the organism (Stephen et al., 2012).

This study aims to use safety and effective materials against root-knot nematode, Meloidogyne incognita that infecting ground cherry plants, to be used as substituent of chemical nematicides which cause damage to human health.

\section{MATERIALS AND METHODS}

Field naturally infested $\left(175.0 \mathrm{~m}^{2}\right)$ was conducted at the experimental farm of the Faculty of Agriculture, Menoufia University, Shibin El-Kom, Egypt, to study the effectiveness of three safety treatments (Potassium silicate; Furfural and Albendazole) individually or solidarity on root-knot nematode, $M$. incognita infecting ground cherry plants in comparison with chemical nematicide Vydate (Oxamyl 24\% L) and their impact on the vegetative and fruiting characteristics of the ground cherry plants.

\section{Potassium silicate}

Potassium silicate $\left[\mathrm{K}_{2} \mathrm{SiO}_{3}\left(\mathrm{SiO}_{2} 25 \%\right.\right.$ \& $\left.\left.\mathrm{K}_{2} \mathrm{O} 10 \%\right)\right]$ was applied as foliar spray at $4000 \mathrm{ppm}$ concentration. The application was started one week after planting the seedlings, then after one, two, three and four months, according to Abdel-Latif et al. (2019).

\section{Furfural}

Furfural (2 furancarbox aldehyde) is a naturally occurring aromatic aldehyde present in some foods, essential plant oils, and cosmetics. It was obtained from Sinopharm company, with a purity of $99.0 \%$.. One week after seedling adaptation, Furfural was applied at a rate of $50 \mathrm{ml} / \mathrm{plant}$ as soil drench around the roots, the same rate was applied two months after planting, according to Fabiyi (2020).

\section{Albendazole}

Albendazole $\left(\mathrm{C}_{12} \mathrm{H}_{15} \mathrm{~N}_{3} \mathrm{O}_{2} \mathrm{~S}\right)$ is one of the most famous medicines for the treatment and disposal of zoo parasitic nematodes. It is produced by Pharma Cure for the pharmaceutical industries in the form of tablets and syrup.

\section{Experimental laboratory (before field experiment):}

A laboratory experiment was conducted to study the effect of Albendazole on root-knot nematode, $M$. incognita $\mathbf{J}_{2}$. Nematodes were extracted from the soil before planting and different concentrations of albendazole $(1 ; 3 ; 5$ and $7 \mathrm{ml})$ were added by 
micropipette on parasitic nematodes placed in Petri dish $(5 \mathrm{~cm}$ diameter) and its activity was monitored under the microscope. It was found that the concentration of 3 $\mathrm{ml}$ led to a weak activity of the nematodes after two hours and after eight hours all the nematodes were died. Albendazole was applied to the soil around the roots of plants at a rate of $3 \mathrm{ml} /$ plant and repeated every month.

Vydate 24\% L., Oxamyl : (2-dimethylthio) glyoxal-0-methylcarbamoyl monoxime) was applied around the roots of plants at a rate of $2 \mathrm{ml} / \mathrm{plant}$.

\section{Experimental preparation and design:}

At transplanting time of ground cherry seedlings cultivar Balady, the nine treatments were arranged in a completely randomized block design. Each treatment was replicated three times (three rows), each row consisted of was 4 meter long and one meter wide. The distance between each two ground cherry seedlings cv. Balady was $50 \mathrm{~cm}$. Normal agricultural practices were undertaken and treatments were as follows : 1. Potassium silicate; 2. Furfural; 3. Albendazole; 4. P. silicate + Furfural; 5. P. silicate + Albendazole; 6. Furfural + Albendazole; 7. P. silicate + Furfural + Albendazole; 8. Oxamyl 24\% L and 9. Control.

Soil samples were taken before planting and nematode extraction was processed using modified Baermann funnels for 72 hours. Different plant parasitic nematode genera were identified and counted using Hawksely counting slide with the aid of Stereomicroscope. Key references of Mai and Lyon (1975) were consulted and found to be of the genus Meloidogyne and traces of other genera like Pratylenchus and Helicotylenchus. Monthly soil samples were taken from the rhizosphere area of ground cherry plants from each treatment for four months. Three replicates, each one of $100 \mathrm{~g}$ soil and roots were taken from each treatment to extract nematodes, counted and identified according to methods described by Southey (1970). At the end of the experiment, 120 days after treatments, plant roots were submerged, thoroughly washed in tap water, immediately stained with Phloxin-B solution $(0.15 \mathrm{~g} / \mathrm{l}$ tap water $)$ for 20 minutes and egg masses were assessed according to Daykin and Hussey (1985). Plant roots were rinsed in water, some of root knot nematode females were counted with the help of a dissecting microscope and according to the perineal pattern, it was found that mostly types follow $M$. incognita. Number of galls were rated on scale of 0-5 (Table 1). Vegetative and fruiting measurements of plants were taken.

Table 1: Rating scale levels of galls numbers (Taylor and Sasser, 1978)

\begin{tabular}{cc}
\hline Number of galls/ root system & Gall index \\
\hline 0 & 0 \\
$1-2$ & 1 \\
$3-10$ & 2 \\
$11-30$ & 3 \\
$31-100$ & 4 \\
$>100$ & 5
\end{tabular}

\section{Statistical analysis}

The obtained data were subjected to analysis of variance (ANOVA) using CoStat Software, Version 6.4 (2008). The mean differences were compared by Least Significant Difference (L.S.D. 5\%). 
Reduction percentages were counted according to the formula of Henderson and Tilton (1955); Fleming and Retnakaran (1985):

Reduction $\%=1-[$ No. of $\mathrm{J} 2$ in treated after treatment/ No. of $\mathrm{J} 2$ in treated before treatment $\mathrm{x}$ No. of $\mathrm{J} 2$ in check before treatment/ No. of $\mathrm{J} 2$ in check after treatment ] $\mathrm{x} 100$

Increase or decrease $\%=$ Control - Treatment $/$ Control x 100

\section{RESULTS AND DISCUSSION}

The application of the treatments led to a gradual decrease in the population density of root-knot nematode, $M$. incognita $\mathrm{J}_{2}$ over a period of four months after planting (Tables $2 \& 3$ ). As for the individual treatments, the furfural gave the highest reduction percentage in $M$. incognita $\mathrm{J}_{2}$ reaching $55.9 \%$, followed by treatment with albendazole $(52.1 \%)$ and the least effective treatment occurred with potassium silicate which gave $39.4 \%$.

Table 2: Effect of certain safe materials applied singly or in combination on the population density of Meloidogne incognita infecting ground cherry plants under field conditions.

\begin{tabular}{|c|c|c|c|c|c|c|}
\hline \multirow{3}{*}{ Treatments } & \multicolumn{6}{|c|}{$\begin{array}{c}\text { Aver. no. of Meloidogyne incognita second stage juveniles/ } 100 \mathrm{~g} \\
\text { soil }\end{array}$} \\
\hline & \multirow[b]{2}{*}{$\begin{array}{c}\text { Pre- } \\
\text { treatment }\end{array}$} & \multicolumn{5}{|c|}{ Months post-treatments } \\
\hline & & $\begin{array}{c}\text { One } \\
\text { month }\end{array}$ & $\begin{array}{c}\text { Two } \\
\text { months }\end{array}$ & $\begin{array}{c}\text { Three } \\
\text { months }\end{array}$ & $\begin{array}{c}\text { Four } \\
\text { months }\end{array}$ & $\begin{array}{c}\text { Overall } \\
\text { mean }\end{array}$ \\
\hline \multirow{2}{*}{ Potassium silicate } & 1699.0 & 1516.0 & 1474.0 & 1302.0 & 1191.0 & 1370.8 \\
\hline & $\mathrm{F}$ & $\mathrm{B}$ & B & B & $\mathrm{B}$ & B \\
\hline \multirow{2}{*}{ Furfural } & 1705.0 & 1414.0 & 1009.0 & 861.0 & 642.0 & 981.5 \\
\hline & $\mathrm{F}$ & $\mathrm{D}$ & $\mathrm{E}$ & $\mathrm{E}$ & $\mathrm{E}$ & $\mathrm{E}$ \\
\hline \multirow{2}{*}{ Albendazole } & 1798.0 & 1476.0 & 1250.0 & 993.0 & 806.0 & 1131.3 \\
\hline & $\mathrm{D}$ & $\mathrm{C}$ & $\mathrm{C}$ & $\mathrm{C}$ & $\mathrm{C}$ & $\mathrm{C}$ \\
\hline \multirow{2}{*}{ P. silicate + Furfural } & 1687.0 & 1329.0 & 981.0 & 706.0 & 593.0 & 902.3 \\
\hline & G & $\mathrm{F}$ & $\mathrm{F}$ & G & $\mathrm{F}$ & $\mathrm{F}$ \\
\hline \multirow{2}{*}{ P. silicate + Albendazole } & 1723.0 & 1403.0 & 1167.0 & 924.0 & 723.0 & 1054.3 \\
\hline & $\mathrm{E}$ & $\mathrm{E}$ & $\mathrm{D}$ & $\mathrm{D}$ & $\mathrm{D}$ & $\mathrm{D}$ \\
\hline \multirow{2}{*}{ Furfural + Albendazole } & 1812.0 & 1417.0 & 1016.0 & 715.0 & 409.0 & 889.3 \\
\hline & $\mathrm{C}$ & $\mathrm{D}$ & $\mathrm{E}$ & $\mathrm{F}$ & G & G \\
\hline P. silicate + Furfural + & 1891.0 & 1294.0 & 844.0 & 395.0 & 107.0 & 660.0 \\
\hline Albendazole & A & G & $\mathrm{H}$ & I & I & I \\
\hline \multirow{2}{*}{ Oxamyl $24 \% \mathrm{~L}$} & 1853.0 & 1329.0 & 946.0 & 639.0 & 381.0 & 823.8 \\
\hline & $\mathrm{B}$ & $\mathrm{F}$ & G & $\mathrm{H}$ & $\mathrm{H}$ & $\mathrm{H}$ \\
\hline \multirow{2}{*}{ Control } & 1808.0 & 2093.0 & 2418.0 & 2576.0 & 2708.0 & 2448.8 \\
\hline & $\mathrm{C}$ & A & A & A & A & A \\
\hline LSD 5\% & 8.6 & 8.6 & 8.6 & 8.6 & 8.6 & 8.5 \\
\hline
\end{tabular}

Means in each column followed by the same letter (s) are not significantly different at $5 \%$ level. 
As for the combined treatments, Potassium silicate + Furfural + Albendazole gave the highest reduction percentage $(96.2 \%)$ in the fourth month, with an average $72.3 \%$ along the four months. The chemical nematicide, Oxamyl, gave $86.3 \%$ reduction in the fourth month with an average $65.6 \%$.

Table 3: Reduction percentages in the population density of root-knot nematode, Meloidogyne incognita infecting ground cherry plants treated with safe materials under field conditions.

Treatments

Reduction \% of M. incognita

\begin{tabular}{lccccc}
\cline { 2 - 6 } & $\begin{array}{c}\text { One } \\
\text { month }\end{array}$ & $\begin{array}{c}\text { Two } \\
\text { months }\end{array}$ & $\begin{array}{c}\text { Three } \\
\text { months }\end{array}$ & $\begin{array}{c}\text { Four } \\
\text { months }\end{array}$ & $\begin{array}{c}\text { Overall } \\
\text { mean }\end{array}$ \\
\hline Potassium silicate & 22.9 & 35.1 & 46.2 & 53.2 & 39.4 \\
Furfural & 28.4 & 55.8 & 64.6 & 74.9 & 55.9 \\
Albendazole & 29.1 & 48.0 & 61.2 & 70.1 & 52.1 \\
P. silicate + Furfural & 31.9 & 56.5 & 70.6 & 76.5 & 58.9 \\
P. silicate + Albendazole & 29.7 & 49.4 & 62.4 & 72.0 & 53.4 \\
Furfural + Albendazole & 32.5 & 58.1 & 72.3 & 85.0 & 62.0 \\
P. silicate + Furfural+Albendazole & 40.9 & 66.6 & 85.3 & 96.2 & 72.3 \\
Oxamyl 24\% L & 38.0 & 61.8 & 75.8 & 86.3 & 65.6 \\
\hline
\end{tabular}

These results are in agreement with those obtained by Fabiyi (2020) who confirmed that furfural has a significant and negative effect on root-knot nematode $M$. incognita in soil and roots on Arachis hypogaea plant. Oka (2001) found that the furfural reduces root-knot nematode and the number of mature females in tomato roots and improves the vegetative and fruiting characteristics of the plants. Abdelnabby et al. (2016) found that furfural inhibited egg hatching after two days of application and eradicated $M$. incognita $\mathrm{J} 2$ after 12 hours, and it has a negative effect on the biology of the different stages of $M$. incognita growth. This occurred by dissolving the lipid layer of the egg shell or the cuticle responsible for the impermeability and thus the eggs and larvae become more permeable and die.

The obtained results in Table (4) show that potassium silicate led to a decrease in the percentage of mature females, egg masses and root gall index by 39.0, 51.1 \& $33.3 \%$, respectively. These results are in agreements with those obtained by Dannon and Wydra (2004) who confirmed that potassium silicate caused increase in plant resistance. Followed by furfural, which caused a decrease of $63.7,70.1 \& 50.0 \%$, respectively and albendazole by $56 ., 65.6 \& 50.0 \%$, respectively. But the tri treatment, Potassium silicate + Furfural + Albendazole is considered the strongest treatment, as it caused a decrease in the percentages of mature females, egg masses and root gall index reached 96.0, 95.4 and 83.3\%, respectively, exceeded those of nematicide, Oxamyl which gave deficiency rates $(86.9,90.5$ and $83.3 \%$, respectively).

Albendazole is considered a safety and inexpensive substance and has proven its effectiveness against root knot nematode, $M$. incognita parasitizing on the roots of the ground cherry plants. Kumsa et al. (2010) recorded that, this material works to eliminate nematodes, it performs this role through a lack of energy by reducing the 
production of ATP energy molecules through the ability to destroy the microcytoplasmic tubes present in the intestines of worms, thus depriving. These worms are unable to obtain the glucose needed for energy, as well as cause a lack of other nutrients, which weakens the movement of nematodes and thus eliminates them.

Table 4: Effect of treating ground cherry plants with safe materials on Meloidogyne incognita mature females, egg masses and root gall index.

\begin{tabular}{|c|c|c|c|c|c|c|}
\hline \multirow[b]{2}{*}{ Treatments } & \multirow[b]{2}{*}{$\begin{array}{l}\text { Mature } \\
\text { females/ } \\
5 \mathrm{~g} / \mathrm{root}\end{array}$} & \multirow[b]{2}{*}{$\begin{array}{c}\text { No } \\
\text { egg } \\
\text { masses }\end{array}$} & \multirow[b]{2}{*}{$\begin{array}{l}\text { Root } \\
\text { gall } \\
\text { index }\end{array}$} & \multicolumn{3}{|c|}{ Decrease $\%$} \\
\hline & & & & Females & $\begin{array}{c}\text { Egg } \\
\text { masses } \\
\text { production }\end{array}$ & $\begin{array}{c}\text { Root } \\
\text { gall } \\
\text { index } \\
\end{array}$ \\
\hline Potassium silicate & $\begin{array}{c}15.3 b \\
b\end{array}$ & $\begin{array}{c}21.3 b \\
b\end{array}$ & $\begin{array}{c}4.0 \mathrm{~b} \\
\mathrm{~B}\end{array}$ & 39.0 & 51.1 & 33.3 \\
\hline Furfural & $\begin{array}{c}9.1 \\
\mathrm{~d}\end{array}$ & $\begin{array}{c}13.0 \\
\mathrm{~cd}\end{array}$ & $\begin{array}{c}3.0 \\
\mathrm{C}\end{array}$ & 63.7 & 70.1 & 50.0 \\
\hline Albendazole & $\begin{array}{c}11.0 \\
\mathrm{c}\end{array}$ & $\begin{array}{c}15.0 \\
\mathrm{c}\end{array}$ & $\begin{array}{c}3.0 \\
\mathrm{C}\end{array}$ & 56.2 & 65.6 & 50.0 \\
\hline P.silicate +Furfural & $\begin{array}{c}6.1 \\
\mathrm{e}\end{array}$ & $\begin{array}{l}9.9 \\
\mathrm{de}\end{array}$ & $\begin{array}{c}2.0 \\
D\end{array}$ & 75.7 & 77.3 & 66.7 \\
\hline P.silicate+Albendazole & $\begin{array}{c}7.3 \\
\mathrm{e}\end{array}$ & $\begin{array}{c}11.0 \\
\text { de }\end{array}$ & $\begin{array}{l}2.0 \\
\mathrm{D}\end{array}$ & 70.9 & 74.8 & 66.7 \\
\hline Furfural + Albendazole & $\begin{array}{c}4.0 \\
\mathrm{f}\end{array}$ & $\begin{array}{c}8.4 \\
\mathrm{e}\end{array}$ & $\begin{array}{l}2.0 \\
\mathrm{D}\end{array}$ & 84.1 & 80.3 & 66.7 \\
\hline $\begin{array}{l}\text { P. silicate }+ \text { Furfural }+ \\
\text { Albendazole }\end{array}$ & $\begin{array}{c}1.0 \\
\mathrm{~g}\end{array}$ & $\begin{array}{c}2.0 \\
\mathrm{f}\end{array}$ & $\begin{array}{c}1.0 \\
\mathrm{E}\end{array}$ & 96.0 & 95.4 & 83.3 \\
\hline Oxamyl $24 \% \mathrm{~L}$ & $\begin{array}{c}3.3 \\
\mathrm{f}\end{array}$ & $\begin{array}{c}4.1 \\
\mathrm{f}\end{array}$ & $\begin{array}{c}1.0 \\
\mathrm{E}\end{array}$ & 86.9 & 90.5 & 83.3 \\
\hline Control & $\begin{array}{c}25.1 \\
\mathrm{a}\end{array}$ & $\begin{array}{c}43.6 \\
\mathrm{a}\end{array}$ & $\begin{array}{c}6.0 \\
\mathrm{~A}\end{array}$ & - & - & - \\
\hline LSD $5 \%$ & 1.7 & 3.3 & 0.2 & - & - & - \\
\hline
\end{tabular}

Means in each column followed by the same letter (s) are not significantly difference at 5\% level.

The obtained results in Table (5) show that, the ability of the treatments to improve the characteristics of the ground cherry plants, as furfural increased plant height; shoot weight; root weight and fruit weight $(\mathrm{g}) / \mathrm{plant}$ by $42.4,34.4,51.7 \&$ $92.9 \%$, respectively, followed by albendazole with proportions of 35.8, 23.0, $30.3 \&$ $65.1 \%$, respectively. Potassium silicate came in the last rank of this respect $(30.0 \%$, $16.4,58.4 \& 45.9 \%$ ) respectively. While tri treatment (Potassium silicate + Furfural + Albendazole) gave the best increments in these proportions $(76.6,99.4,97.8 \&$ $236.2 \%$, respectively) compared with nematicide Oxamyl which gave 47.3, 43.7, 40.4 \& $170.5 \%$, respectively. These results are comfortable with Mamdouh et al.( 2017); Abdel-Latif et al. (2019) hence they are confirmed that potassium silicate improves the physiological response of plant leaves while increasing the ability to photosynthesis, thus improving the ability to resist diseases and parasites, and improving the vegetative and fruiting characteristics of onion plants. Gad (2019) found that, treating the cotton plant with potassium silicate leads to the entry of silica into the structure of the cell walls and the formation of silicon-containing polymers that make the cell walls more rigid and thus be resistant to reniform nematode penetration, so the plant becomes resistant to a higher degree. 
Table 5: Effect of treating ground cherry plants with safe materials to control Meloidogyne incognita vegetative and fruiting characteristics of plants.

\begin{tabular}{|c|c|c|c|c|c|c|c|c|}
\hline \multirow[b]{2}{*}{ Treatments } & \multirow[b]{2}{*}{$\begin{array}{l}\text { Plant } \\
\text { height } \\
(\mathrm{cm})\end{array}$} & \multirow[b]{2}{*}{$\begin{array}{c}\text { Shoot } \\
\text { weight } \\
\text { (g) }\end{array}$} & \multirow[b]{2}{*}{$\begin{array}{l}\text { Root } \\
\text { weight } \\
\text { (g) }\end{array}$} & \multirow{2}{*}{$\begin{array}{c}\text { Fruit } \\
\text { weight } \\
\text { (g) } \\
\text { /plant }\end{array}$} & \multicolumn{4}{|c|}{ Increase $\%$} \\
\hline & & & & & $\begin{array}{l}\text { Plant } \\
\text { height }\end{array}$ & $\begin{array}{c}\text { Shoot } \\
\text { weight }\end{array}$ & $\begin{array}{c}\text { Root } \\
\text { weight }\end{array}$ & $\begin{array}{c}\text { Fruit } \\
\text { weight }\end{array}$ \\
\hline Potassium silicate & $\begin{array}{c}80.6 \\
\mathrm{~F} \\
\end{array}$ & $\begin{array}{c}21.3 \\
\mathrm{E} \\
\end{array}$ & $\begin{array}{c}14.1 \\
\mathrm{~d}\end{array}$ & $\begin{array}{c}217.5 \\
\mathrm{~g}\end{array}$ & 30.0 & 16.4 & 58.4 & 45.9 \\
\hline Furfural & $\begin{array}{c}88.3 \\
\mathrm{D} \\
\end{array}$ & $\begin{array}{c}24.6 \\
\mathrm{D} \\
\end{array}$ & $\begin{array}{c}13.5 \\
\mathrm{~d}\end{array}$ & $\begin{array}{c}287.5 \\
\mathrm{e} \\
\end{array}$ & 42.4 & 34.4 & 51.7 & 92.9 \\
\hline Albendazole & $\begin{array}{c}84.2 \\
\mathrm{E} \\
\end{array}$ & $\begin{array}{c}22.5 \\
\mathrm{E} \\
\end{array}$ & $\begin{array}{c}11.6 \\
\mathrm{f} \\
\end{array}$ & $\begin{array}{c}246.0 \\
\mathrm{f} \\
\end{array}$ & 35.8 & 23.0 & 30.3 & 65.1 \\
\hline P. silicate+Furfural & $\begin{array}{c}96.1 \\
\mathrm{C} \\
\end{array}$ & $\begin{array}{c}31.0 \\
\mathrm{Bc} \\
\end{array}$ & $\begin{array}{c}16.5 \\
\mathrm{~b}\end{array}$ & $\begin{array}{c}317.0 \\
\mathrm{~d}\end{array}$ & 55.0 & 69.4 & 85.4 & 112.7 \\
\hline P. silicate + Albendazole & $\begin{array}{c}94.9 \\
\mathrm{C}\end{array}$ & $\begin{array}{c}29.5 \\
\mathrm{C}\end{array}$ & $\begin{array}{c}15.0 \\
\mathrm{c} \\
\end{array}$ & $\begin{array}{c}294.0 \\
\mathrm{e}\end{array}$ & 53.1 & 61.2 & 68.5 & 97.3 \\
\hline Furfural + Albendazole & $\begin{array}{c}103.0 \\
\mathrm{~B} \\
\end{array}$ & $\begin{array}{c}32.1 \\
\mathrm{~B} \\
\end{array}$ & $\begin{array}{c}16.9 \\
\mathrm{ab}\end{array}$ & $\begin{array}{c}384.5 \\
\mathrm{c} \\
\end{array}$ & 66.1 & 75.4 & 89.8 & 158.1 \\
\hline $\begin{array}{l}\text { P. silicate }+ \text { Furfural }+ \\
\text { Albendazole }\end{array}$ & $\begin{array}{c}109.5 \\
\mathrm{~A} \\
\end{array}$ & $\begin{array}{c}36.5 \\
\mathrm{~A} \\
\end{array}$ & $\begin{array}{c}17.6 \\
\mathrm{a} \\
\end{array}$ & $\begin{array}{c}501.0 \\
\mathrm{a} \\
\end{array}$ & 76.6 & 99.4 & 97.8 & 236.2 \\
\hline Oxamyl 24\% L & $\begin{array}{c}91.3 \\
\mathrm{D} \\
\end{array}$ & $\begin{array}{c}26.3 \\
\mathrm{D} \\
\end{array}$ & $\begin{array}{c}12.5 \\
\mathrm{e}\end{array}$ & $\begin{array}{c}403.0 \\
\mathrm{~b}\end{array}$ & 47.3 & 43.7 & 40.4 & 170.5 \\
\hline Control & $\begin{array}{c}62.0 \\
\mathrm{G} \\
\end{array}$ & $\begin{array}{c}18.3 \\
\mathrm{~F} \\
\end{array}$ & $\begin{array}{c}8.9 \\
\mathrm{~g}\end{array}$ & $\begin{array}{c}149.0 \\
\mathrm{~h} \\
\end{array}$ & - & - & - & - \\
\hline LSD $5 \%$ & 3.4 & 1.7 & 0.9 & 8.6 & - & - & - & - \\
\hline
\end{tabular}

Means in each column followed by the same letter (s) are not significantly difference at 5\% level

Initially, Albendazole is uniquitous and inimitable as a human nematode exterminator (Stephen et al., 2012). In the present study it was introduced as a first trial not only in Egypt but also globally as exterminator against root- knot nematode in agricultural pest control. Its solidarity with both of furfural as organic nematicide and potassium silicate which promote ground cherry growth properties as stemifol nutritional supplement against $M$. incognita infection. In the present study tri treatments gave amazing results with highly nematode reduction percentage exceeded that occurred by nematicide Oxamyl appliance. Finally, forthright on the bases of safety, aptly, forceful, cheapest, competency and environmentally friendly alternatives of these exterminators qualified in hence forward as substituent of chemical nematicide in integrated nematode control program.

\section{REFERENCES}

Abdelnabby, H.; Wang, Y.; Xiao, X.; Wang, G.; Yang, F. and Xiao,Y. (2016). Impact of direct and indirect application of rising furfural concentrations on viability, infectivity and reproduction of the root knot nematode, Meloidogyne incognita in Pisum sativum. Microb. Pathog. 96:26-34.

Abdel-Latif, Amany A.; Ibrahim, M. and Ismail, A. (2019). Effect of foliar application of potassium silicate and some postharvest treatments on growth, productivity and storability of Garlic. AUJAS, Ain Shams Univ., Cairo, Egypt, Special Issue, 27 (1): $761-773$.

Abo-Korah, M.S. (2017). Biological control of root-knot nematode, Meloidogyne javanica infected Ground Cherry using two nematophagous and mychorrhizal Fungi. Egypt. J. Bio. Pest Cont. 27(1): 111-115.

CoStat software program (Version 6.4). CoStat version 6.400 Copyright- $($ C 1998-2008 
Cohort Software.798 Lighthouse Ave. PMB 320, Monterey,CA, 93940, USA.

Dannon, E.A. and Wydra K. (2004). Interaction between silicon amendment, bacterial wilt development and phenotype of Ralstonia solanacearum in tomato genotypes. Physiol. Mol. Plant Pathol. 64(5):233-243.

Daykin, M. E. and Hussey, R.S. (1985). Staining and histopathological techniques in nematology. In: Barker, K. R.; C. C. Carter and J. N. Sasser (eds), An Advanced treatise on Meloidogyne, Vo. II Methodology, 39-48. North Carolina State University Graphics, Raleigh.

Fabiyi, O. A. (2020). Growth and yield response of groundnut [Arachis hypogaea (Linn)] under Meloidogyne incognita infection to furfural synthesised from agro-cellulosic materials. J. Trop. Agri. 58 (2): 241-245.

Fleming, R. and Retnakaram, A. (1985). Evaluating single treatment data using Abbot's formula with reference to insecticides. J. Econ. Entom. 78: $1179-$ 1181.

Gad, S. B. (2019). Efficacy of soaking cotton seeds within salicylic acid and potassium silicate on reducing reniform nematode infection. Arch. Phytopathol.Plant. Prot. 52 (15-16): 1149-1160.

Henderson, C. F. and Tilton, W. (1955). Tests with acaricides against the brown wheat mite. J. Econ. Entomol. 48: 157 - 161.

Kumagai, M.; Yoshida I.; Mishima1, T.; Ide, M.; Fujita, K.; Doe, M.; Nishikawa, K.

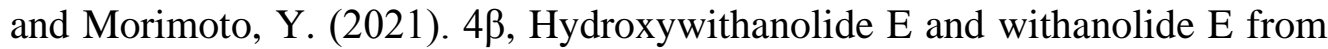
Physalis peruviana L. inhibit adipocyte differentiation of 3T3-L1 cells through modulation of mitotic clonal expansion. J. Nat. Med. 75:232-239.

Kumsa, B.; Tolera, A. and. Nurfeta,A. (2010). Comparative efficacy of seven brands of albendazole against naturally acquired gastrointestinal nematodes in sheep in Hawassa, southern Ethiopia. Turk. J. Vet. Anim. Sci. 34(5): 417-425.

Mai, W.F. and Lyon, H. H. (1975). Plant-Parasitic Nematodes: A Pictorial Key to Genera (Comstock Books) Publisher: Peter G. Mullin, Cornell University Press; 5 th edition, $277 \mathrm{pp}$.

Mamdouh, M.A.; Fetian, N.A.; Medhat, S.; Abdel Magid, S. and El-Sheery, N.I. (2017). Effectiveness of potassium silicate in suppression white rot disease and enhancement physiological resistance of onion plants, and its role on the soil. Middle East J. Agri. Res. 6(2): 1-19.

Oka, Y. (2001). Nematicidal activity of essential oil components against root-knot nematode Meloidogyne javanica. Nematol. 3: 159-164.

Puente, L. A.; Pinto-Muñoz, C. A.; Castro, E. S. and Cortés, M. (2011). Physalis peruviana Linnaeus, the multiple properties of a highly functional fruit: A review. Food Research International. 44: 1733-1740.

Saad, A. S.; Massoud, M. A.; Ibrahim, H. S. and. Khalil, M.S. (2010). Nematicidal Effect of biological control agents and other chemical compounds on Meloidogyne incognita infesting tomato plants. Alexandria Sci. Exchange J. 31 (3): 240-245.

Southey, J. F. (1970). Laboratory methods for work with plant and soil nematodes. Ministry of Agriculture, Fishers and Food. Technical Bulletin 2: 5 th ed., 148 pp.

Stephen, J.; Swanson, M.D.; Christina, R.; Phares Ph.D.; Blain Mamo M.P.; Kirk E.; Smith D.V.M.; Ph.D.; Martin S.; Cetron M.D. and M.D. William (2012). Albendazole Therapy and Enteric Parasites in United States-Bound Refugees. The N. Engl. J. Med. 366: 1498-1507.

Taylor, A.L. and Sasser, J.A. (1978). Biology, Identification and Control of Root-knot 
Nematodes (Meloidogyne spp.). Coop Publ. Dep. Plant Pathology North Carolina, State University and US. Agency Int. Dev. Raleigh, NC.111 pp.

Ye M.; Song Y.Y.; Long, J.; Wang, R.L.; Baerson, S.R. and Pan, Z.Q. (2013). Priming of jasmonate-mediated antiherbivore defense responses in rice by silicon. Proc. Natl. Acad. Sci. U.S.A. 110:3631-3639.

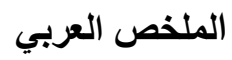

\section{Meloidogyne incognita تأثثر بعض المعاملات الصديقة للبيئة على نيماتودا تعقد الجذور

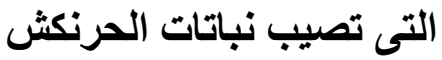

محمد سعيد ابوقورة

$$
\text { قسم الحشرات الاقتصادية والحيوان الزراعى ـ كلية الزر اعة - جامعة المنوفية - مصر }
$$

يتجه العلماء حاليا إلى تقليص إستخدام المبيدات النيماتودية الكيمبائية والثائعة التو اجد في الأسواق وتبعاً لذلك زاد الطلب على بدائل آمنه وفعاله وصديقة للبيئة ، ومن ثم جاءت فكرة هذا البحث بتطبيق ثلاث مواد آمنة


الحقلية و هذه المو اد هي ( Potassium silicate; Furfural ; Albendazole) فردي أوثنائي او ثلاثي مقارنة بالمبيد النيماتودى الاوكساميل. M. أظهرت نتائج التجربة الى أن جميع المعاملات التي نم تطبيقها أدت إلى نقص الكثافة العددية لنيماتودان incognita

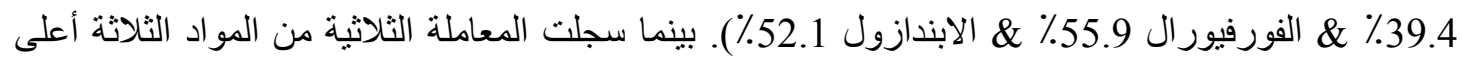
نسب موت للايدان النيماتودية تحت الدراسة وصلت إلى (72.3 \%) متفوقة على المبيد النيماتودي الكيميائي الاوكساميل و الذي أعطى نسبة موت وصلت إلى (65.6 \%) فقطو علية فقد سجلت المعاملة الثلاثية نقصاً ملحوظاً في أعداد كلا من الإناث البالغة و عدد كتل البيض و العقد الجذرية بنسب نقص وصلت إلى (96.5 \% \& 95.4 ٪


( 83.3 علاوة على ما سبق كان للمعاملة الثلاثية السبق في تحسين كل من الصفات الخضرية والثمرية لنباتات الحرنكش، وبالتالي يمكن الاعتماد على هذة المعاملة الثثلاثية كبديل آمن للإنسان والنبات من تطبيق المبيدات النيماتودية في بر امج المكافحة المتكاملة للنيماتودا المتطفلة على النبات. 